(

9

\title{
Evaluation of a Recessive Male Floret Color in Cultivated Northern Wild Rice (Zizania palustris L.) for
} Pollen-Mediated Gene Flow Studies

\section{Clare Gietzel $^{1}$, Jacques Duquette ${ }^{2}$, Lillian McGilp ${ }^{1}$, and Jennifer Kimball ${ }^{1}$}

${ }^{1}$ Department of Agronomy and Plant Genetics, University of Minnesota, St. Paul, MN 55108, USA; ${ }^{2}$ North Central Research and Outreach Center, University of Minnesota, Grand Rapids, MN 55744, USA Corresponding Author: Dr. Jennifer Kimball, jkimball@umn.edu Keywords: northern wild rice, Zizania palustris, pollen travel, pollen-mediated gene flow

\section{Abstract}

Northern wild rice (NWR; Zizania palustris L.) is a wind-pollinated, annual, aquatic grass that grows naturally in the Great Lakes Region (GLR) of the United States and Canada, and is also cultivated in flooded paddies, predominantly in California and Minnesota. A better understanding of pollen-mediated gene flow is needed within the species for both conservation and breeding efforts as cultivation occurs within the species natural range and spatially-isolated, paddy structures are limited within breeding programs. Widely cited pollen travel research in NWR demonstrated that pollen could travel at least $3200 \mathrm{~m}$. However, a population segregating for male sterility was used as the pollen recipient in the study and was determined to not be adequate for NWR pollen travel studies. Here, we present the characterization of a recessive white male floret (WMF) population in contrast to the dominant, purple male floret (PMF) color of cultivated NWR along with estimates of pollen-mediated gene flow in a cultivated paddy setting. Studies conducted in 2018 and 2019 revealed that the primary amount of pollen-mediated gene flow occurred within the first $7 \mathrm{~m}$ from the PMF donor source with no gene flow detected past $63 \mathrm{~m}$. These results suggest that the likelihood of pollen-mediated gene flow between cultivated NWR and natural stands remains low. We also identified a strong linkage between male floret, auricle, and culm color. This study demonstrates that the WMF trait is an excellent candidate for use in pollen-mediated gene flow studies in NWR.

8




\section{Introduction}

Pollen-mediated gene flow in outcrossing species often represents the movement of unwanted alleles from one population to another. This movement can affect varietal purity and cause crop-to-wild or weedy relative gene flow (Ellstrand et al., 2003). The dispersion of pollen can depend on numerous factors including pollen viability, flowering synchrony, weather conditions, and surrounding vegetation (Shivanna et al., 1991; Gliddon et al., 1999; Thompson et al., 1999). In particular, weather conditions, such as wind speed, wind direction, and relative humidity, significantly affect pollen travel trends in wind-pollinated species (Latta and Mitton, 1999; Steinitz et al., 2011; Born et al., 2012). Despite this heavy environmental influence, most models predict the rapid dissipation of pollen densities following release from the source (Messeguer et al., 2006; Sarangi et al., 2017). For breeders and conservationists alike, an understanding of pollen travel trends for species of interest can aid in eliminating or reducing unwanted pollen-mediated gene flow.

The movement of pollen can be monitored using a wide range of techniques. Traps to track the physical movement and deposition of pollen, mostly commonly sedimentation and filtration traps, have been used across a range of species (Kearns and Inouye, 1993; Mullins and Emberlin, 1997). Other trapping methods involve the use of marked or tagged pollen (Moon et al., 2006). Specifically tracking pollenmediated gene flow requires the use of morphological traits, such as kernel color (Hanson et al., 2005; Bannert and Stamp, 2007), cone size (Zobel, 1951), and leaf hair density (Hardig et al., 2000), or molecular markers, which can track specific genes (Ouborg et al., 1999). Molecular markers, in particular, have played an important role in tracking gene movement from genetically modified (GM) crops to non-GM varieties, landraces, and weedy relatives (Ma et al., 2004; Watrud et al., 2004; Pla et al., 2006).

Northern Wild Rice (NWR), Zizania palustris L., is an annual, wind-pollinated aquatic grass native to the Great Lakes Region of North America. It is a protogynous, monoecious species and its female florets are located above male florets on the panicle. Cultivation of the species began in Minnesota in the 1950s (Oelke et al., 1982) and has since become a high-valued specialty crop in major markets (Tuck, 2019). 
open-pollinated populations (Grombacher et al., 1997). Spatially-isolated, permanent paddy structures are

57 limited within breeding programs, necessitating a better understanding of pollen travel trends, especially within short distances, to maintain the genetic purity of breeding lines (Ireland et al., 2006; Baltazar et al., 2015). Additionally, cultivation occurs within the species' center of origin, where the conservation of natural stands in lakes and streams is imperative to the maintenance of genetic diversity and delicate ecosystems. NWR is considered an indicator of overall ecosystem health, providing food and habitat for a variety of wildlife (Rogosin, 1954; Fannucchi, 1983). Therefore, an understanding of potential gene flow from natural stands to cultivated paddies and vice versa is an integral aspect of pollen travel research in 64 NWR.

Initial pollen travel studies in NWR found diurnal pollen release patterns, similar to those in corn and other grass species, with the highest pollen concentrations occurring between 1200-1700 hours, 20$23^{\circ} \mathrm{C}, 50-60 \%$ relative humidity, and wind speeds of 7.5-9 kph (Cregan, 2004). Previous NWR pollen travel research also included the utilization of a bottlebrush (BB) population (Cregan, 2004), with a compact male flower morphology, linked to an uncharacterized male sterility gene (Stucker et al., 1984; Grombacher et al., 1997). Cregan (2004) reported that NWR pollen could travel at least 3200m, a number that has been

71 widely cited as validation of concerns regarding pollen-mediated gene flow in NWR. However, the BB trait

72 is considered inadequate for NWR pollen travel studies due to the somewhat weak linkage between the BB

73 trait and male sterility, leading to pollen-producing BB plants and resulting seed set (contamination). In this

74 study, we compare two populations of cultivated NWR, with either a recessive white male floret (WMF)

75 or a dominant, purple male floret (PMF), and use them to estimate pollen-mediated gene flow in a cultivated

76 paddy setting. This study demonstrates that the WMF trait is an excellent candidate for use in pollen-

77 mediated gene flow studies in NWR.

\section{Materials and Methods}

81 
82

83

84

85

86

87

Plant Material. In this study, a homozygous recessive WMF population (Figure 1a) was utilized to estimate pollen-mediated gene flow in NWR. Multiple PMF populations (Figure 1b) were utilized as pollen donors to maximize the flowering synchronicity between WMF and PMF populations. The 2018 flowering period for the WMF population was from July $15^{\text {th }}$ to August $15^{\text {th }}$ and from July $25^{\text {th }}$ to August $25^{\text {th }}$ in 2019 .

Weather Data. Wind speed $(\mathrm{km} / \mathrm{h})$ and direction data were collected from the National Oceanic and Atmospheric Administration (NOAA) weather station located at the Itasca County Airport in Grand Rapids, $\mathrm{MN}$, approximately 3.3 miles from the trial. Air temperature $\left({ }^{\circ} \mathrm{C}\right)$ and accumulated precipitation $(\mathrm{mm})$ were collected from an automated weather station at the Grand Rapids U.S. Forest Research Service Lab in Grand Rapids, MN, approximately 0.5 miles from the trial.

Pollen Travel Experiments. Experiments were conducted at the University of Minnesota North Central Research and Outreach Center (NCROC) in Grand Rapids, Minnesota (47.2372 ${ }^{\circ}$ N, $93.5302^{\circ} \mathrm{W}$, and 392 m elevation) at the cultivated NWR paddy complex, where individual paddies have $1-1.5 \mathrm{~m}$ raised dikes for irrigation purposes. In 2018, twenty $3 \mathrm{~m}$ x $6 \mathrm{~m}$ WMF plots with $3 \mathrm{~m}$ single rows spaced $0.38 \mathrm{~m}$ apart and $1 \mathrm{~m}$ alleys were planted at $15.7 \mathrm{~kg} \mathrm{ha}^{-1}$. These plots were planted $3 \mathrm{~m}$ south/southeast of a $24-$ plot $(12 \mathrm{~m} \mathrm{x} 41 \mathrm{~m})$ PMF trial, which served as the purple pollen donor (Figure 2a). At its farthest distance, a WMF plot was a maximum of 35m from a PMF plot (north to south). In 2019, the experiment was expanded to include larger pollen travel distances and forty-four $3 \mathrm{~m}$ x $6 \mathrm{~m}$ WMF plots were planted with the northwestern-most plot consisting of multiple PMF genotypes (Figure 2b). The maximum distance between a WMF plot and the PMF plot was 9m, west-east, and 70m, north-south. The experimental design for these experiments was largely dictated by the size and shape of paddies ( $15-25 \mathrm{~m}$ wide and $\sim 90 \mathrm{~m}$ long), which eliminated the possibility of planting a PMF plot in the middle of a large WMF plot to evaluate 360 degrees of pollen travel from the source. Instead, common summer wind patterns were utilized to establish dominant wind directions at the paddy complex, resulting in the PMF donor source being planted directly north of the WMF plots. 
Paddies were amended with $16.7 \mathrm{~kg} \mathrm{ha}^{-1}$ Environmentally Safe Nitrogen (ESN), $9.3 \mathrm{~kg} \mathrm{ha}^{-1}$ urea, and $7.4 \mathrm{~kg} \mathrm{ha}^{-1}$ potassium. Immediately following planting, paddies were flooded to $20 \mathrm{~cm}$ average water depth. Copper sulfate (1.13 $\mathrm{kg} \mathrm{ha}^{-1}$ rate) was used to control algal growth and Aquabac (200G) (Bacillus thuringiensis subsp. israelensis - Becker Microbial Products, Coral Springs FL; $1.86 \mathrm{~kg} \mathrm{ha}^{-1}$ rate) to control aquatic pests, specifically midge larvae. Plots were monitored daily for PMF plants in the WMF plots, which were rogued prior to pollen set. Individual WMF plots were harvested each year, processed, and stored in the dark, at $3^{\circ} \mathrm{C}$, on water, for the duration of the seed dormancy period.

Progeny Testing. For both years of the study, 50-100 stratified seeds per WMF plot were germinated on petri dishes lined with filter paper and hydrated with $10 \mathrm{ml}$ of $\mathrm{H}_{2} \mathrm{O}$. The petri plates were placed at an ambient temperature of $\sim 23^{\circ} \mathrm{C}$, under LabLink LED LabLights (PG LifeLink, Erlanger, KY), set to a 16hr day length. After 10 days, $5 \mathrm{~cm}$ long seedlings were transplanted into individual $25 \mathrm{~cm}$ deep plant cones, submerged in 680L aquaponics tanks. The soil in each cone was amended with $22.4 \mathrm{~kg} \mathrm{ha}^{-1} \mathrm{~N}$, in the form of urea, and $0.125 \mathrm{~g}$ iron chelate. Throughout growth and flowering, plants were monitored daily for culm, due to the COVID-19 global pandemic.

Data Analysis. Monthly mean air temperature was calculated by averaging the daily maximum and minimum air temperature values. Cumulative precipitation was calculated by adding together the daily precipitation, in millimeters, for all days in a given time period. Analysis of wind speed and direction data was conducted using R 4.0.1 (R Core Team, 2020), and the OpenAir package (Carslaw \& Ropkins, 2012) was used to generate wind roses with the use of ggplot2 and ggplotify (Wickham, 2016; Yu, 2020). Wind run, or the total distance that the wind traveled over a given timeframe, was calculated on a $24 \mathrm{hr}$ basis by multiplying the average wind speed by the amount of time elapsed per data point. Data was collected hourly 
134

135

136

137

138

139

140

141

142

143

144

145

146

147

148

149

150

151

152

153

154

155

156

157

158

159

unless a shift in wind direction occurred, in which case, another data point was generated. In order to analyze differences in wind run per plot, the degree range for each of the 16 cardinal directions was superimposed onto each plot map and wind directions that conferred a high probability of wind traveling through pollen donor PMF plots to each WMF plot was determined. An empirical model of pollen-mediated gene flow was obtained by regressing the hybridization rate on the maximum distance from the PMF pollen source using the NLIN procedure in SAS statistical software package v9.4 (SAS Institute, 2013) similar to Schmidt et al. (2013). The negative exponential model: hybridization rate $=\alpha^{-\beta \text { (distance) }}$ was used. The suitability of the model fit was verified using regression coefficients.

Percent hybridization per plot was calculated as the proportion of WMF plot progeny with purple male florets over the total progeny tested. To evaluate the effect of distance from the PMF source, the distance in meters from the closest edge of the PMF plot(s) to the furthest edges of each WMF plot was measured and then pooled for each range of the experiment. Recombination frequencies between culm, auricle, and male floret color were calculated using parental (all white or all purple phenotypes) and recombinant class data from 2018. The number of plants in each recombinant class divided by the total number of observed parental phenotypes provided estimates of genetic linkage in centiMorgans (cM) between the three traits.

\section{Results and Discussion}

Weather Data. Throughout the growing period in 2018 , the mean air temperature $\left({ }^{\circ} \mathrm{C}\right)$ was generally warmer than the 20-year average for Grand Rapids, Minnesota but in 2019, it was cooler than the 20-year average (Table 1). Temperature differences between 2018 and 2019 were minimal, with the exception of May and August, when it was more than $2^{\circ} \mathrm{C}$ cooler in 2019. During the 2018 and 2019 flowering periods (July $15^{\text {th }}$-August $15^{\text {th }}$ and July $25^{\text {th }}$-August $25^{\text {th }}$, respectively), weekly mean air temperatures varied widely. The last week of July and first week of August were peak flowering weeks during both years and had a mean air temperature of $20.00^{\circ} \mathrm{C}$ and $17.98^{\circ} \mathrm{C}$ in 2018 , and $13.89^{\circ} \mathrm{C}$ and $19.1^{\circ} \mathrm{C}$ in 2019 , respectively. In 
160

161

162

163

164

165

166

167

168

169

170

171

172

173

174

175

176

177

178

179

180

181

182

183

184

185

other Poaceae species, temperature is known to affect anther ripening, where warmer weather can confer higher concentrations of shed pollen (Hart et al., 1994), while low temperatures can reduce meiotic efficiency during anthesis (Zeng et al., 2017). Cregan (2004) found NWR pollen shed to be highest between $20-23^{\circ} \mathrm{C}$, which suggests warm, but not hot, temperatures improve pollen shed. It is possible that the low temperatures during the first week of peak flowering in 2019 decreased pollen shed. However, more research regarding the relationship between temperature and pollen shed in NWR is needed to validate this conclusion.

Monthly precipitation $(\mathrm{mm})$ in 2018 was similar to the 20 year average with the exception of the month of August, which was $\sim 43 \%$ drier than the 20 year average (Table 1). In 2019, monthly precipitation levels were highly variable from month to month during the growing season and their 20 year averages. May, July, and August were drier in comparison, while June and September were wetter. When comparing 2018 and 2019, accumulation varied widely between the months. During the flowering periods, plots received a total of $12.96 \mathrm{~mm}$ of precipitation in 2018 and $78.22 \mathrm{~mm}$ in 2019 . While the effect of precipitation on pollen travel in NWR has not been previously explored, studies have shown that pollen concentration in the air decreases significantly on rainy days, as rain washes pollen grains from the air (Scott, 1970; Hart et al., 1994). In 2018, there were 11 days during the 30-day flowering period with rainfall, however only 3 of those days accumulated to more than $1 \mathrm{~mm}$. In 2019, there were 17 days of recorded rainfall during the 30-day flowering period but only 11 with more than $1 \mathrm{~mm}$.

Wind direction and speed are primary drivers of pollen travel in wind-pollinated species. In 2018, winds originated predominantly from the northwest and southeast, while winds in 2019 primarily arose from the south (Figure 3). In 2018, 33\% of the wind came from the northwest (NW, NNW, WNW), and $\sim 31 \%$ came from the south (S, SSE, SSW). In 2019, $\sim 23 \%$ of the wind came from the northwest, while $\sim 46 \%$ came from the south (Figure 3). ). Mean wind speeds were similar between years with speeds reaching $7.9 \mathrm{~km} / \mathrm{h}$ in 2018 , and $8.2 \mathrm{~km} / \mathrm{h}$ in 2019 . Both years had similar amounts of calm air during the flowering periods (38.4\% and $36.4 \%$, respectively). Both years had similar levels of calm air during the flowering periods (38.4\% and 36.4\%, respectively). Both years also had similar frequencies of high speed 
186

187

188

189

190

191

192

193

194

195

196

197

198

199

200

201

202

203

204

205

206

207

208

209

210

211

wind. During the flowering period in both years, approximately $1 \%$ of the wind that blew was characterized as a "fresh breeze," defined as $29-38 \mathrm{~km} / \mathrm{h}$ in the Beaufort scale. In $2018,7 \%$ of the wind that blew was considered a moderate breeze $(20-28 \mathrm{~km} / \mathrm{h})$, compared with $8 \%$ in 2019 . There were more days during the 2019 flowering period with recorded wind gusts (20) than in 2018 (16). There is scientific evidence to suggest that a slight variation in wind speed, irrespective of an increase or decrease, has a greater effect on pollen travel than higher wind speed alone (Sauliene and Veriankaite, 2012) and therefore, these wind gusts may play an important role in moving NWR pollen from the pollen donor source.

Distance and Direction of Pollen Travel. Detection of PMF pollen-mediated gene flow in WMF plots ranged from $0-19 \%$ and $0-48 \%$ in 2018 and 2019, respectively (Figure 2). In both years, the highest rate of PMF penetrance occurred within the WMF plots bordering or closest to the PMF donor plot(s). This suggests that the highest percentage of pollen-mediated gene flow within NWR occurs within the first $7 \mathrm{~m}$ of the pollen donor source. Beyond a 7m N-S distance, pollen-mediated gene flow from PMF plots to WMF plots ranged from $1.24 \%-5.32 \%$ in 2018 (up to $35 \mathrm{~m}$ tested) and $0.00-2.44 \%$ in 2019 (up to $70 \mathrm{~m}$ tested) (Table 2). No gene flow was detected past $63 \mathrm{~m}$. However, it is important to note that pollen density would be higher in a larger production field, which could result in higher rates of hybridization. The higher rates of pollen penetrance into the 2018 plots may have been influenced by the amount of donor pollen available per the experimental design, the higher mean air temperatures, or the lower amounts of precipitation in 2018. While we are unable to confirm using this dataset, we hypothesize that PMF pollen penetrance in 2019 beyond 49m was caused by contaminant PMF plants that were not identified and rogued in WMF plots prior to pollen shed. These contaminant plants were identified in plots 1934 and 1935 . However, further studies need to be conducted to confirm this. Despite this possibility, the estimates of pollenmediated gene flow in this study were comparable to those identified in other grass species. In both maize (Zea mays) (Messeguer et al., 2006) and common waterhemp (Amaranthus rudis Sauer) (Sarangi et al., 2017), evidence of pollen-mediated gene flow via wind was found within the first 50m surrounding pollen donor plants but then dropped off considerably. 
To investigate the relationship between the rate of hybridization in WMF plots and distance from the purple pollen donor source among years, we fit a curve to the data from each year and compared the

214 confidence intervals for $\alpha$ and $\beta$ (Table 3). The model was deemed appropriate for the description of pollen-

215 mediated gene flow in both years by the highly significant parameter estimates and the non-zero confidence

216 intervals. However, this empirical model only includes distance as a predictive factor of pollen-mediated

217 gene flow and does not account for other environmental factors, such as wind. Therefore, we generated an

218 ANOVA using a multiple regression model including distance and wind run. Both variables had a 219 significant effect in both years during the flowering periods. In this regression model, distance had the 220 biggest impact on the rate of hybridization in 2018, while wind run had a bigger impact on hybridization in

2212019 (Table 4). The significant interaction between distance and wind run indicates that distance from the

222 pollen source as well as wind speed and its proportion have an impact on hybridization. These results

223 suggest that as distance from the pollen source increases, wind becomes a more important factor in the rate 224 of hybridization, a phenomenon that has been identified in other species as well (Hanson et al., 2005; 225 Schmidt et al., 2013). While we suggest the possibility that contamination could have led to hybridization 226 at greater distances, it is also possible that wind speed and direction could have led to hybridization from 227 the purple pollen source. male floret color. To assess the degree of linkage, observations of floret, culm and auricle color were

232 collected in 2018. Of the 335 analyzed plants, only three plants displayed recombinant genotypes between

233 male floret color, culm color, and auricle color with an estimated $0.9 \mathrm{cM}$ separating culm and auricle color 234 genes (Figure 1g). The limited recombination between these three traits indicates they are tightly linked, 235 which will be helpful for progeny testing in future WMF travel studies, as culm and auricle color can be evaluated at earlier stages of development. Genes for purple coloration (anthocyanin accumulation) in 
237

238

239

240

241

242

243

244

245

246

247

248

249

250

251

252

253

254

255

256

various plant parts have been identified in other grain crops including wheat, triticale, and white rice (Dhulappanavar, 1973; Dhulappanavar, 1979; Zeven, 1985).

\section{Conclusions}

This study confirmed that the utilization of the male floret color as a means to track pollen-mediated gene flow in NWR is an effective strategy, as long as the WMF seed source is not contaminated with seed harboring the purple male floret color. The contamination in the WMF seed sources highlights the difficulties of controlling pollen travel in cultivated NWR breeding programs. However, pollen-mediated gene flow in this study was limited beyond $7 \mathrm{~m}$ from the pollen donor source, providing estimates of pollenmediated gene flow for establishing new pollen travel mitigation strategies in irrigated paddy settings. The limited range of pollen-mediated gene flow in NWR is further supported by genetic diversity studies that have estimated high genetic differentiation between different lake and river populations of NWR, suggesting limited gene flow among populations (Lu et al., 2005; Xu et al., 2015). These results suggest that the possibility of pollen-mediated gene flow between cultivated NWR and natural stands remains low. However, Halsey et al. (2005) indicated that the relative amount of pollen produced from the pollen source is an important factor when evaluating pollen-mediated gene flow in species. Our study was small in scale in comparison to cultivated paddies as well as natural stands in lakes and river systems. In the future, we suggest a large-scale on-farm study, similar to Cregan (2004), is necessary to effectively determine maximum pollen travel distances in NWR. Additionally, while we identified that air temperature, rainfall, and wind patterns play a role in the distance of pollen travel in NWR, more research is needed to fully understand the effect of weather conditions on pollen travel. 


\section{References}

Baltazar, B.M., L.C. Espinoza, A.E. Banda, J.M. De La Fuente Martínez, J.A.G. Tiznado, et al. 2015. Pollen-mediated gene flow in maize: Implications for isolation requirements and coexistence in Mexico, the center of origin of maize. PLoS One 10(7). doi: 10.1371/journal.pone.0131549.

Bannert, M., and P. Stamp. 2007. Cross-pollination of maize at long distance. Eur. J. Agron. 27(1): 44-51. doi: 10.1016/j.eja.2007.01.002.

Born, C., P.C. Le Roux, C. Spohr, M.A. McGeoch, and B.J. Van Vuuren. 2012. Plant dispersal in the subAntarctic inferred from anisotropic genetic structure. Mol. Ecol. 21(1): 184-194. doi: 10.1111/j.1365294X.2011.05372.x.

Carslaw, D. C. and K. Ropkins, (2012) openair --- an R package for air quality data analysis. Environmental Modelling \& Software. Volume 27-28, 52-61.

Cregan, J.L. 2004. Aspects of seed storage, pollen travel and population dynamics of wildrice (Zizania palustris). (Master's Thesis, University of Minnesota).

Dhulappanavar, C.V. 1973. Linkage Studies in Rice (Oryza sativa L.). Euphytica 22: 555-561.

Dhulappanavar, C.V. 1979. Linkage Studies in Rice (Oryza sativa L.): Flowering, Growth Habit and Pigmentation. Euphytica 28: 435-443.

Ellstrand, N.C., S.C.H. Barrett, S. Linington, A.G. Stephenson, and L. Comai. 2003. Current knowledge of gene flow in plants: Implications for transgene flow. Philos. Trans. R. Soc. B Biol. Sci. 358(1434): 1163-1170. doi: 10.1098/rstb.2003.1299.

Fannucchi, W. A. (1983). Wildlife use of wild rice beds and the impact of rice harvesting on wildlife in east central Minnesota (Doctoral dissertation, University of Wisconsin-Stevens Point, College of Natural Resources).

Gliddon, C., P. Boudry, and S. Walker. 1999. Gene flow-a review of experimental evidence. Environ. Impact Genet. Modif. Crop: 65-79.

Grombacher, A.W., R.A. Porter, and L.A. Everett. 1997. Breeding Wild Rice. Plant Breed. Rev. 14: 237265. doi: 10.1002/9780470650073.ch8.

Halsey, M.E., K.M. Remund, C.A. Davis, M. Qualls, P.J. Eppard, et al. 2005. Isolation of maize from pollen-mediated gene flow by time and distance. Crop Sci. 45(6): 2172-2185. doi: 10.2135/cropsci2003.0664.

Hanson, B.D., C.A. Mallory-Smith, B. Shafii, D.C. Thill, and R.S. Zemetra. 2005. Pollen-mediated gene flow from blue aleurone wheat to other wheat cultivars. Crop Sci. 45(4): 1610-1617. doi: 10.2135/cropsci2004.0443.

Hardig, T.M., S.J. Brunsfeld, R.S. Fritz, M. Morgan, and C.M. Orians. 2000. Morphological and molecular evidence for hybridization and introgression in a willow (Salix) hybrid zone. Mol. Ecol. 9(1): 9-24. doi: 10.1046/j.1365-294X.2000.00757.x.

Hart, M.L., J.E. Wentworth, and J.P. Bailey. 1994. The effects of trap height and weather variables on recorded pollen concentration at leicester. Grana 33(2): 100-103. doi: 10.1080/00173139409427840. 
Ireland, D.S., D.O. Wilson, M.E. Westgate, J.S. Burris, and M.J. Lauer. 2006. Managing reproductive isolation in hybrid seed corn production. Crop Sci. 46(4): 1445-1455. doi: 10.2135/cropsci2004.0007.

Kearns, C.A., and D.W. Inouye. 1993. Techniques for pollination biologists. University press of Colorado.

Latta, R.G., and J.B. Mitton. 1999. Historical Separation and Present Gene Flow through a Zone of Secondary Contact in Ponderosa Pine. Evolution (N. Y). 53(3): 769. doi: 10.2307/2640717.

Lu, Y., D.M. Waller, and P. David. 2005. Genetic variability is correlated with population size and reproduction in American wild-rice (Zizania palustris var. palustris, Poaceae) populations. Am. J. Bot. 92(6): 990-997. doi: 10.3732/ajb.92.6.990.

Ma, B.L., K.D. Subedi, and L.M. Reid. 2004. Extent of cross-fertilization in maize by pollen from neighboring transgenic hybrids. Crop Sci. 44(4): 1273-1282. doi: 10.2135/cropsci2004.1273.

Messeguer, J., G. Peñas, J. Ballester, M. Bas, J. Serra, et al. 2006. Pollen-mediated gene flow in maize in real situations of coexistence. Plant Biotechnol. J. 4(6): 633-645. doi: 10.1111/j.14677652.2006.00207.x.

Moon, H.S., M.D. Halfhill, L.C. Hudson, R.J. Millwood, and C. Neal Stewart. 2006. Expression of green fluorescent protein in pollen of oilseed rape (Brassica napus L.) and its utility for assessing pollen movement in the field. Biotechnol. J. 1(10): 1147-1152. doi: 10.1002/biot.200600113.

Mullins, J., \& Emberlin, J. (1997). Sampling pollens. Journal of Aerosol Science, 28(3), 365-370.

Oelke, E.., J. Grava, D. Noetzel, D. Barron, J. Percich, et al. 1982. Wild Rice Production in Minnesota. Minnesota Agricultural Experiment Station Report.

Ouborg, N.J., Y. Piquot, and J.M. Van Groenendael. 1999. Population genetics, molecular markers and the study of dispersal in plants. J. Ecol. 87(4): 551-568. doi: 10.1046/j.1365-2745.1999.00389.x.

Pla, M., J.L. La Paz, G. Peñas, N. García, M. Palaudelmàs, et al. 2006. Assessment of real-time PCR based methods for quantification of pollen-mediated gene flow from GM to conventional maize in a field study. Transgenic Res. 15(2): 219-228. doi: 10.1007/s11248-005-4945-x.

R Core Team (2020). R: A language and environment for statistical computing. R Foundation for Statistical Computing, Vienna, Austria. URL https://www.R-project.org/.

Rogosin, A. 1954. An Ecological Life History of Wild Rice. Minnesota, Department of Conservation, Division of Game and Fish, Fisheries Research Unit.

Sarangi, D., A.J. Tyre, E.L. Patterson, T.A. Gaines, S. Irmak, et al. 2017. Pollen-mediated gene flow from glyphosate-resistant common waterhemp (Amaranthus rudis Sauer): Consequences for the dispersal of resistance genes. Sci. Rep. 7(November 2016): 1-16. doi: 10.1038/srep44913.

Sauliene, I., and L. Veriankaite. 2012. Analysis of high allergenicity airborne pollen dispersion: common ragweed study case in Lithuania. Ann. Agric. Environ. Med. 19(3): 415-419. http://agro.icm.edu.pl/agro/element/bwmeta1 .element.agro-168609a4-ed75-448c-b781a150dd1c9865.

Schmidt, J.J., J.F. Pedersen, M.L. Bernards, and J.L. Lindquist. 2013. Rate of shattercane $\times$ sorghum hybridization in situ. Crop Sci. 53(4): 1677-1685. doi: 10.2135/cropsci2012.09.0536. 
67

Scott, R.K. 1970. The effect of weather on the concentration of pollen within sugar-beet seed crops. Ann. Appl. Biol. 66(1): 119-127. doi: 10.1111/j.1744-7348.1970.tb04609.x.

Shivanna, K.R., H.F. Linskens, and M. Cresti. 1991. Pollen viability and pollen vigor. Theor. Appl. Genet. 81(1): 38-42. doi: 10.1007/BF00226109.

Steinitz, O., D. Troupin, G.G. Vendramin, and R. Nathan. 2011. Genetic evidence for a Janzen-Connell recruitment pattern in reproductive offspring of Pinus halepensis trees. Mol. Ecol. 20(19): 4152-4164. doi: 10.1111/j.1365-294X.2011.05203.x.

Stucker, R.E., G.L. Linkert, W.E. Palm, and J. Hernandez. 1984. Minnesota Wild Rice Research 1983. Minnesota Agricultural Experiment Station Report.

Thompson, C.E., G. Squire, G.R. Mackay, J.E. Bradshaw, and J. Crawford. 1999. Regional patterns of gene flow and its consequence for GM oilseed rape. Monogr. Crop Prot. Counc.: 95-100.

Tuck, B. 2019. Economic contribution of the cultivated wild rice industry in Minnesota. Cultivated Minnesota Wild Rice Council Report.

Watrud, L.S., E.H. Lee, A. Fairbrother, C. Burdick, J.R. Reichman, et al. 2004. Evidence for landscapelevel, pollen-mediated gene flow from genetically modified creeping bentgrass with CP4 EPSPS as a marker. Proc. Natl. Acad. Sci. U. S. A. 101(40): 14533-14538. doi: 10.1073/pnas.0405154101.

Wickham, H. 2016. ggplot2: Elegant Graphics for Data Analysis. Springer-Verlag New York.

Xu, X.W., J.W. Wu, M.X. Qi, Q.X. Lu, P.F. Lee, et al. 2015. Comparative phylogeography of the wild-rice genus Zizania (Poaceae) in eastern Asia and North America. Am. J. Bot. 102(2): 239-247. doi: 10.3732/ajb.1400323.

Yu, G. (2020). ggplotify: Convert Plot to 'grob' or 'ggplot' Object. R package version 0.0.5. https://CRAN.Rproject.org/package=ggplotify

Zeng, Y., Y. Zhang, J. Xiang, N.T. Uphoff, X. Pan, et al. 2017. Effects of low temperature stress on spikeletrelated parameters during anthesis in indica-Japonica hybrid rice. Front. Plant Sci. 8(August): 1-11. doi: 10.3389/fpls.2017.01350.

Zeven, A.C. 1985. The genetics of auricle colour of wheat (Triticum aestivum L.): A review. Euphytica 34(2): 233-236. doi: 10.1007/BF00022914.

Zobel, B. 1951. The Natural Hybrid between Coulter and Jeffrey Pines. Evolution (N. Y). 5(4): 405-413. 
372

373

374

375

Table 1. Weather data including mean air temperature $\left({ }^{\circ} \mathrm{C}\right)$ and precipitation $(\mathrm{mm})$ during the growing season of 2018 and 2019 in Grand Rapids, Minnesota. Yearly precipitation values are totaled per month and cumulative precipitation values (in parentheses) give the running total for the entire growing season.

\begin{tabular}{|l|l|r|r|r|r|r|r|}
\hline & & \multicolumn{2}{|c|}{ Mean Air Temperature $\left({ }^{\circ} \mathrm{C}\right)$} & \multicolumn{2}{|c|}{ Monthly Precipitation $(\mathrm{mm})$} \\
\hline Month & PGS $^{\dagger}$ & $\mathbf{2 0 1 8}$ & $\mathbf{2 0 1 9}$ & $\begin{array}{c}\mathbf{2 0} \text { Year } \\
\text { Average }\end{array}$ & $\mathbf{2 0 1 8}$ & $\mathbf{2 0 1 9}$ & $\begin{array}{c}\text { 20 Year } \\
\text { Average }\end{array}$ \\
\hline May & 0 & 15.16 & 9.44 & 11.92 & $95.50(95.50)$ & $45.72(45.72)$ & 87.00 \\
\hline June & $1-2$ & 17.83 & 16.81 & 17.35 & $119.38(214.88)$ & $151.13(196.85)$ & 115.06 \\
\hline July & $2-5$ & 20.39 & 20.38 & 20.50 & $82.55(297.43)$ & $61.21(258.06)$ & 84.84 \\
\hline August & $5-8$ & 19.07 & 16.30 & 18.88 & $35.05(332.49)$ & $61.47(319.53)$ & 79.86 \\
\hline September & $7-9$ & 13.72 & 14.52 & 14.36 & $80.26(412.75)$ & $117.35(436.88)$ & 81.56 \\
\hline
\end{tabular}

376

377

378

379

380

381

382

383

384

385

386

387

388

389

390

391

392

393

394

395

396

397 
Table 2. Effect of north-south (N-S) distance from the pollen donor source on pollen-mediated gene flow from purple male floret (PMF) northern wild rice plots to white male floret (WMF) plots in Grand Rapids,

400 Minnesota during the 2018 and 2019 seasons.

\begin{tabular}{|l|c|c|}
\hline & \multicolumn{2}{|c|}{ Hybridization rate (0.0093SE) } \\
\hline $\begin{array}{l}\text { N-S Distance } \\
(\mathbf{m})\end{array}$ & $\mathbf{2 0 1 8}$ & $\mathbf{2 0 1 9}$ \\
\hline $1-7$ & $13.07 \%$ & $9.20 \%$ \\
\hline $8-14$ & $5.32 \%$ & $0.00 \%$ \\
\hline $15-21$ & $1.74 \%$ & $0.00 \%$ \\
\hline $22-28$ & $1.24 \%$ & $2.38 \%$ \\
\hline $29-35$ & $3.92 \%$ & $0.00 \%$ \\
\hline $36-42$ & - & $2.44 \%$ \\
\hline $43-49$ & - & $2.41 \%$ \\
\hline $50-56$ & - & $2.35 \%$ \\
\hline $57-63$ & - & $1.22 \%$ \\
\hline $64-70$ & - & $0.00 \%$ \\
\hline
\end{tabular}

401

402

403

404

405

406

407

408

409

410

411

412

413

414

415

416

417

418 
Table 3. Analysis of variance and parameter estimates obtained by fitting hybridization frequency to distance from the source population using the model: frequency of hybridization $=\alpha \exp (-\beta \times$ distance $)$.

\begin{tabular}{|l|l|l|l|l|l|l|l|l|l|}
\hline Year & Source & df & MSE $^{\dagger}$ & P>F & Coefficient & Estimate & SE & \multicolumn{2}{|l|}{$\begin{array}{l}\text { Confidence } \\
\text { Interval }\end{array}$} \\
\hline $\mathbf{2 0 1 8}$ & Model & 2 & 0.0427 & $<0.0001$ & $\alpha$ & 0.2524 & 0.0272 & 0.1952 & 0.3096 \\
\hline & Error & 18 & 0.0009 & & $\beta$ & 0.0199 & 0.0016 & 0.0166 & 0.0232 \\
\hline $\mathbf{2 0 1 9}$ & Model & 2 & 0.0540 & 0.0003 & $\alpha$ & 0.1256 & 0.0282 & 0.0686 & 0.1826 \\
\hline & Error & 41 & 0.0055 & & $\beta$ & 0.0076 & 0.0014 & 0.0048 & 0.0104 \\
\hline
\end{tabular}

423 
bioRxiv preprint doi: https://doi.org/10.1101/2021.01.26.428335; this version posted January 27, 2021. The copyright holder for this preprint (which was not certified by peer review) is the author/funder, who has granted bioRxiv a license to display the preprint in perpetuity. It is made available under aCC-BY-NC-ND 4.0 International license.

447 Table 4. Analysis of variance tests for the effects of distance and wind run on the frequency of hybridization 448 in 2018 and 2019.

\begin{tabular}{|l|l|l|r|l|}
\hline Year & & df & F value & P value \\
\hline 2018 & Distance & 1 & 18.916 & 0.0005 \\
\hline & Wind Run & 1 & 5.690 & 0.0298 \\
\hline & Distance * Wind Run & 1 & 9.795 & 0.0065 \\
\hline 2019 & Distance & 1 & 10.811 & 0.0021 \\
\hline & Wind Run & 1 & 31.505 & 0.0002 \\
\hline & Distance * Wind Run & 1 & 7.997 & 0.0074 \\
\hline
\end{tabular}

449

450

451

452

453

454

455

456

457

458

459

460

461

462

463

464

465

466

467

468

469

470

471 
472 Figure 1. Phenotypes of the purple male floret (PMF) and white male floret (WMF) colors in northern 473 wild rice (NWR). The left side of the figure represents white phenotypes while the right side represents 474 purple phenotypes. A/B, C/D, and E/F represent the male floret, auricle, and culm, respectively. Finally, G 475 represents the putative recombination map for the genes associated with these traits.

476 Figure 2. Plot maps of 2018-2019 pollen travel experiments in northern wild rice (NWR) along with 477 progeny testing results, which indicate purple male floret (PMF) hybridization rates in the white male floret 478 (WMF) progeny. White boxes represent 100\% WMF plots and purple boxes represent varying degrees of 479 PMF densities.

480 Figure 3. Wind trends during the 2018 and 2019 flowering periods at the Itasca County Airport in Grand 481 Rapids, MN. Wind trends show wind blowing toward the direction specified. 


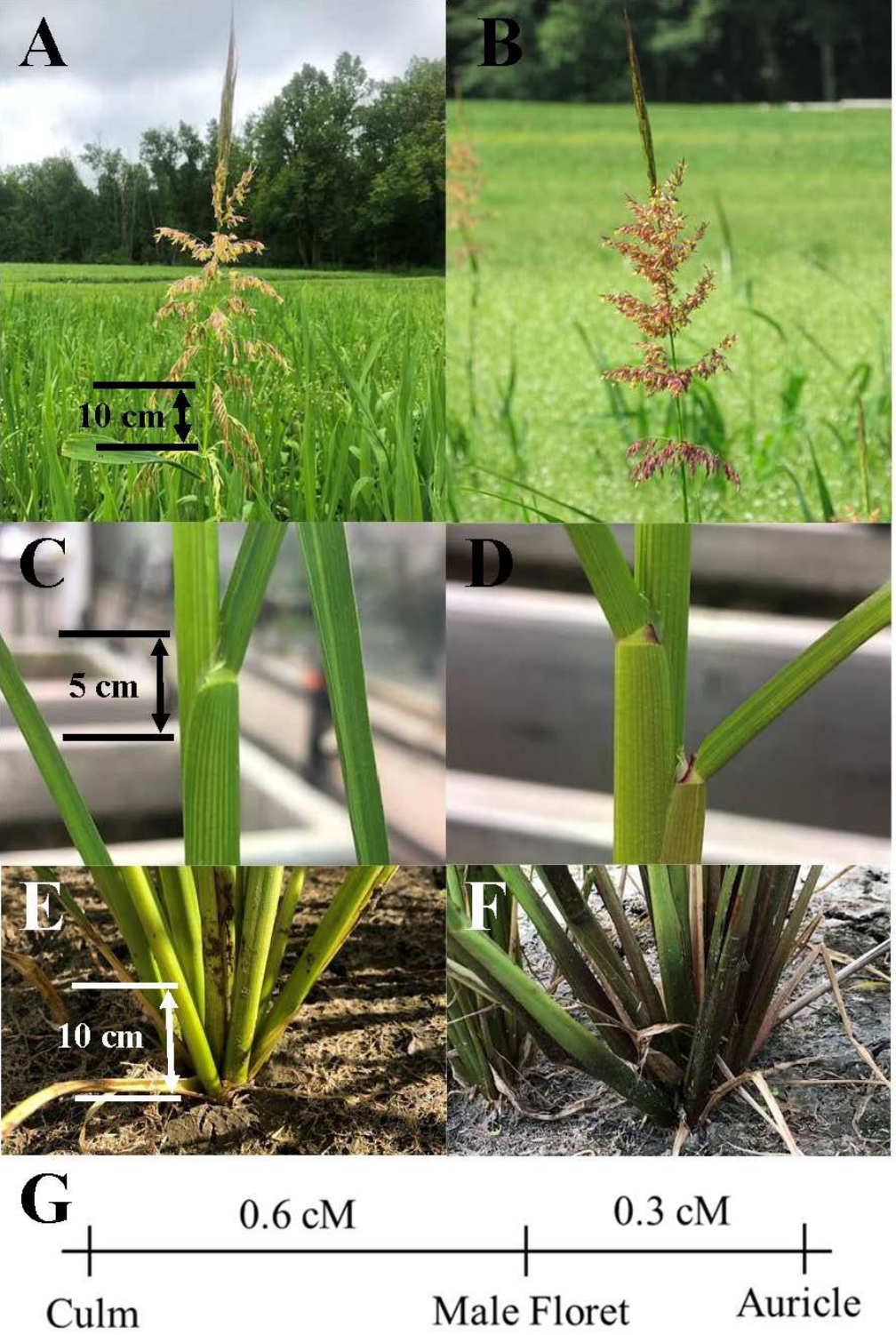




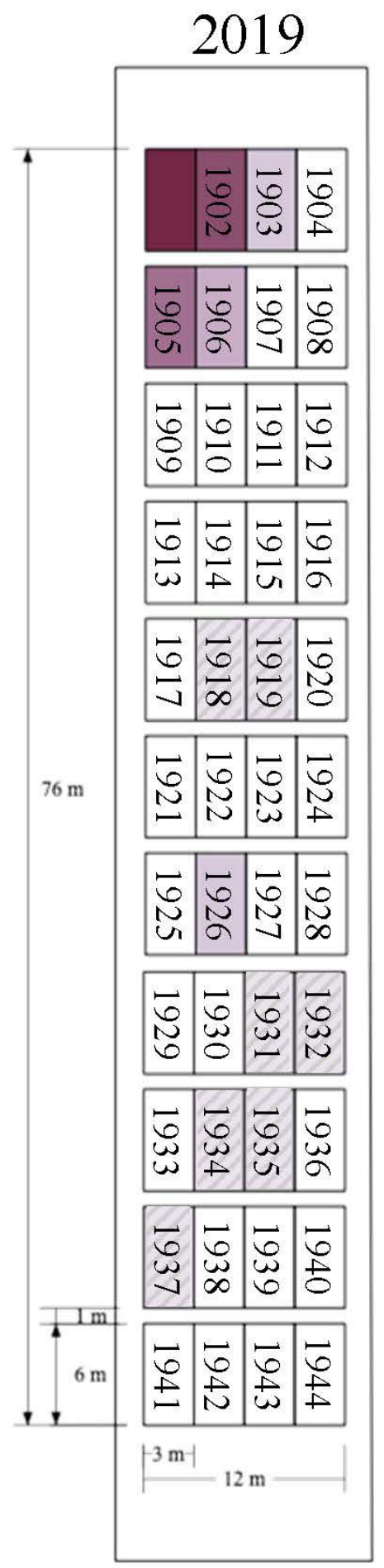

2018
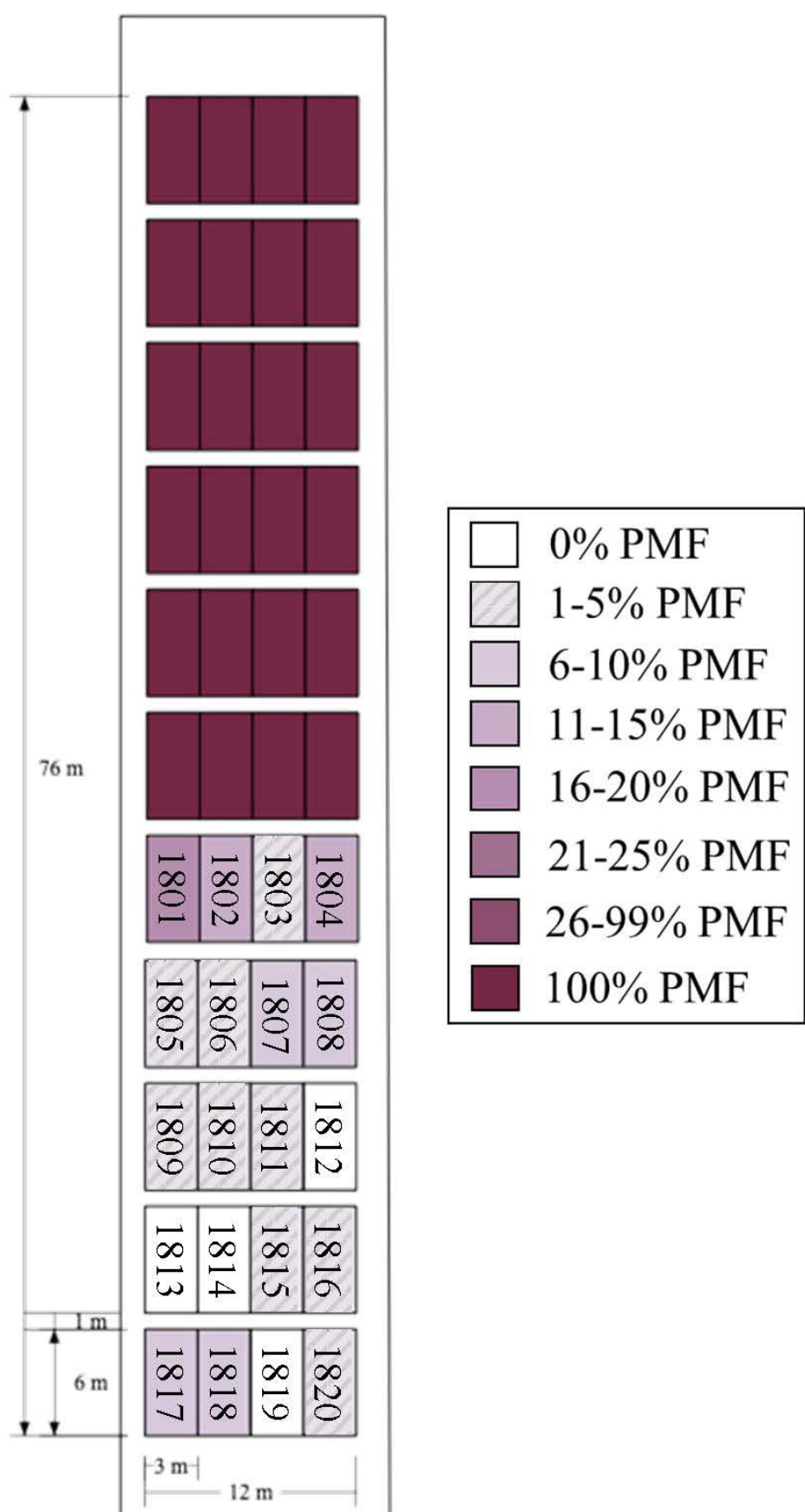

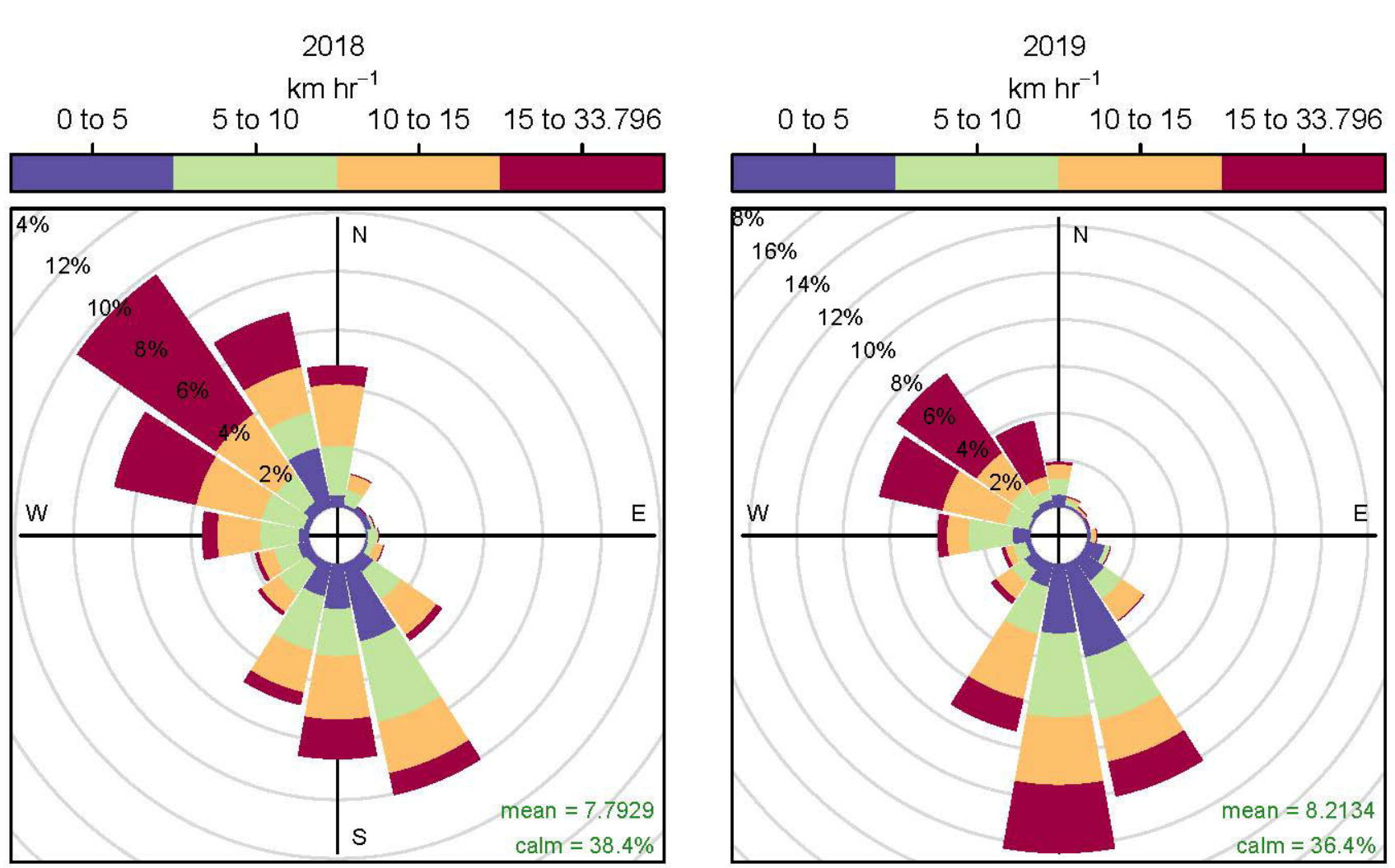

Frequency of counts by wind direction (\%) Frequency of counts by wind direction (\%) 